\title{
Students' Perception on the Attainment of Learning Outcomes of an Undergraduate project-based Final Semester Course (Professional Communication Practice)
}

Nazarul Azali Razali, Ameiruel Azwan Ab Aziz, Amirah Mohd Juned, Nor Atifah Mohamad, Sheik Badrul Hisham Jamil Azhar

To Link this Article: http://dx.doi.org/10.6007/IJARBSS/v11-i10/11461～DOI:10.6007/IJARBSS/v11-i10/11461

Received: 03 August 2021, Revised: 24 August 2021, Accepted: 21 September 2021

Published Online: 16 October 2021

In-Text Citation: (Razali et al., 2021)

To Cite this Article: Razali, N. A., Aziz, A. A. A., Juned, A. M., Mohamad, N. A., \& Azhar, S. B. H. J. (2021). Students' Perception on the Attainment of Learning Outcomes of an Undergraduate project-based Final Semester Course (Professional Communication Practice). International Journal of Academic Research in Business and Social Sciences, 11(10), $1008-1023$.

Copyright: (C 2021 The Author(s)

Published by Human Resource Management Academic Research Society (www.hrmars.com) This article is published under the Creative Commons Attribution (CC BY 4.0) license. Anyone may reproduce, distribute, translate and create derivative works of this article (for both commercial and non-commercial purposes), subject to full attribution to the original publication and authors. The full terms of this license may be seen at: http://creativecommons.org/licences/by/4.0/legalcode

Vol. 11, No. 10, 2021, Pg. $1008-1023$ 


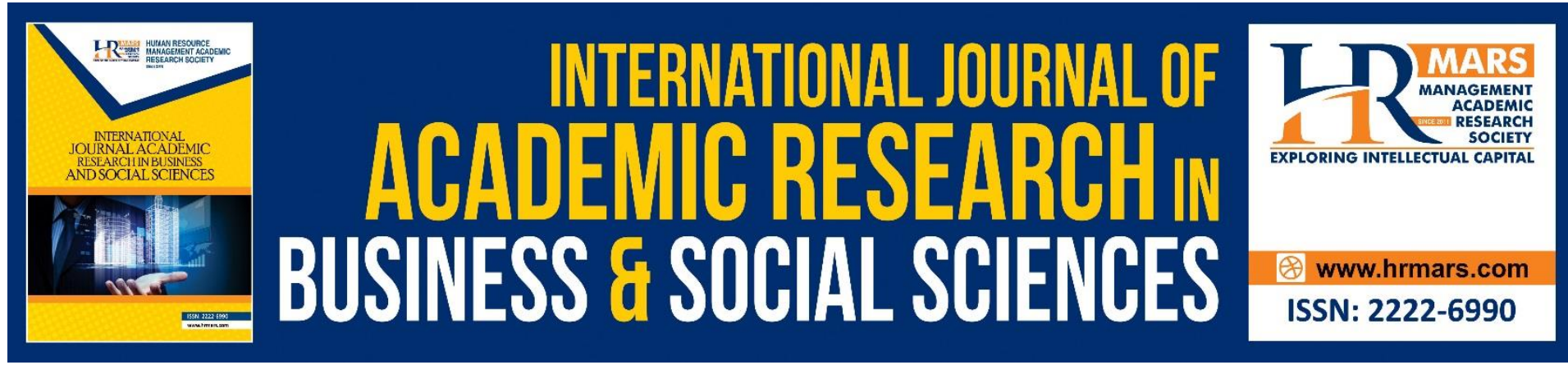

\title{
Students' Perception on the Attainment of Learning Outcomes of an Undergraduate project- based Final Semester Course (Professional Communication Practice)
}

\author{
Nazarul Azali Razali, Ameiruel Azwan Ab Aziz, Amirah Mohd \\ Juned, Nor Atifah Mohamad, Sheik Badrul Hisham Jamil Azhar \\ Akademi Pengajian Bahasa, Universiti Teknologi MARA Cawangan Melaka \\ Email: nazarul@uitm.edu.my, ameirul@uitm.edu.my, amirahjuned@uitm.edu.my, \\ atifah740@uitm.edu.my, sheik835@uitm.edu.my
}

\begin{abstract}
In the Malaysian tertiary education system, adopting an outcome-based approach has emphasised the importance of learning outcomes where setting and determining what can be accomplished at the end of a learning programme is essential to the students' and programme's success. For a new Diploma in English for Professional Communication programme in UiTM, complying with MQF programme standards is vital for obtaining and maintaining accreditation. Institutions also need to report the students' perception of whether programme and course designs have managed to achieve the intended learning outcomes. This study investigated the perception of students on which of the attributes or sub-attributes of MQF's learning outcomes for this final-semester project-based course they believe they have achieved. An online survey was conducted with 63 final semester students of LG120 Diploma in English for Professional Communication from Universiti Teknologi MARA Cawangan Melaka and Universiti Teknologi MARA Cawangan Johor. The findings revealed that students believed the course design had highly impacted their skills in 'making adjustments to process and practices', 'planning and organisational skills', and 'identifying selfimprovement opportunities for further education'. The students also highly regarded the attributes in the course learning outcomes and other MQF attributes/sub-attributes descriptors. This study has shown that students' perception is invaluable when evaluating and determining learning outcomes and strengthens the view that students' beliefs must be considered when writing or designing a learning programme, courses, and learning outcomes. Keywords: Course Learning Outcomes, English for Professional Communication, Professional Communication Exercise, Project-based Work, Students' Perception
\end{abstract}

Introduction 
The influence of outcome-based education (OBE) in the Malaysian education system has been enormous. This approach has been practised in Malaysia since the 1950s and has lately been widely implemented, especially in higher learning (Mohayidin et al., 2008). In higher education, the outcome-based approach is widely considered as the best practice in designing and gauging learning programmes offered by institutions (Gosling \& Moon, 2001). The focus on outcomes allows for the expectations of the programme developer to be more transparent to the students, governing authorities, and accreditation bodies (Gosling \& Moon, 2001). OBE also enables learning and assessment approaches to be well-planned (Zain, Hadi, \& Hamid, 2016). The importance for the tertiary system to adopt this approach can be seen by the various documents that list guidelines and standards to be met by the synergy between institutions and stakeholders. The outcome-based approach also emphasises the importance of learning outcomes where setting and determining what can be accomplished at the end of a learning programme is vital to the students' and programme's success (Mrunal, 2017). In students' achievements, success is often measured and reported by students' academic marks and grades presented in a spiderweb of learning outcomes. The learning outcomes between academic courses, programmes and institutions may be written according to their discipline's specific requirements, but all are standardised according to the Malaysian Qualifications Framework (MQF 2.0) document (Malaysian Qualifications Agency, 2017). In the case of a new Diploma in English for Professional Communication programme in UiTM, complying with MQF programme standards is vital for the ongoing process of obtaining and maintaining accreditation and complying with programme standards. Institutions need to report the students' perception of whether programme and course designs have managed to achieve the intended learning outcomes. Most of the time, students do not understand the course objectives and learning outcomes and are not aware of how the design is related to the course outcomes, prompting some to suggest that students must be made to understand the importance of learning outcomes so that they know the content of their learning and what they should achieve upon completion of the course (Aziz, Yusof, \& Yatim, 2012). Furthermore, reporting students' grades and their achievement to learning outcomes' attributes is often based on what course and programme designers have pre-determined during the inception of the course or programme. Thus, the present study responds to the need to investigate the perception of students on which of the attributes or sub-attributes of MQF's learning outcomes aimed for this final-semester project-based course that they believe they have accomplished.

\section{Current Research}

This study explores the learning outcomes attributes/sub-attributes of Practical Skills and Personal and Entrepreneurial Skills that students believe they have engaged during project development, portfolio preparation, and poster presentation assessments. Two questions were answered in this study are:

1. What attributes/sub-attributes of Practical Skills and Personal and Entrepreneurial Skills were employed by students during the Project and Portfolio assessments?

2. What attributes/sub-attributes of Practical Skills and Personal and Entrepreneurial Skills were employed by students during the Poster Presentation assessment?

\section{Literature Review}




\section{MQF Learning Outcomes, MQF Programme standards, and LG120}

Learning outcomes are descriptions of what a learner is expected to learn, understand, or should be able to demonstrate at the end of learning in a course or programme (Aithal \& Kumar, 2016; Gosling \& Moon, 2001; Malaysian Qualifications Agency, 2017). Writing clear and straightforward course learning outcomes is very important as it helps in the overall design of the course and making sure it complements the right programme and ministerial learning outcomes, as well as making it easier for tutors and students to easily apply the approaches necessary for the outcomes (Elsheikh, Sarudin, \& Gunawan, 2017; Keshavarz, 2011). The monitoring of OBE and accreditation processes of higher learning programmes are undertaken in Malaysia by the Malaysian Qualification Agency (MQA). Course Learning Outcomes (CLO) are part of a complex process to design programme as they are required to align to the Programme Outcomes (PO), Programme Educational Objectives (PEO), and MQF's domains/clusters of learning outcomes (Elsheikh, Sarudin, \& Gunawan, 2017; Malaysian Qualifications Agency, 2017). The five clusters of learning outcomes as stated by the MQF are (i) knowledge and understanding, (ii) cognitive skills, (iii) functional work skills-focus on practical skills, interpersonal skills, communication skills, digital skills, numeracy skills, and leadership, autonomy and responsibility, (iv) personal and entrepreneurial skills, and (v) ethics and professionalism (Malaysian Qualifications Agency, 2017, 2019). For the Diploma in English for Professional Communication (LG120), the PEOs, PLOs, and CLOs still adhere to the learning outcomes listed previously but are guided by attributes and descriptors specialised for language-based programmes. This programme is a relatively new programme that began enrolment in 2018. The planning for this programme began in 2010. It was then aligned to MQA's previous Code of Practice for Programme Accreditation 2008 (Jailani et al., 2015) but has since gone through various changes and realignment of its PEOs, PLOs, and CLOs, according to the MQAs Malaysian Qualifications Framework 2.0 (2017) and Programme Standards: Language (2019). One of the courses offered in this programme is a final semester project-based course, Professional Communication Practice. For this course, students are required to undertake individual projects of their choosing that would reflect skills and learning experiences that they have attained during the previous two years of studies. Each student will be assigned a lecturer cum supervisor to guide them. The CLOs specified for this course are (CLO1) performs essential methods and procedures related to English professional communication discipline, and (CLO2) initiate entrepreneurial mindsets in performing essential methods and procedures related to English professional communication discipline. CLO1 is mapped to MQF's Domains of Learning Outcomes Cluster 3, Functional Work Skillsfocus on Practical Skills, while CLO2 is mapped against Cluster 4, Personal and Entrepreneurial Skills. The attainment of these CLOs is to be assessed by the project's portfolio and poster presentation.

\section{Project-based Work}

Recently, there have been concerns that higher education programmes have become immersed in theory learning instead of hands-on, practical work. Project-based work, which can be part of practical work, offers tertiary students the opportunity to delve into studentcentred learning to hone their knowledge and skills acquired from an academic source based on their interests, abilities, and learning styles with the lecturer as supervisor (Halim et al., 2014). In addition, Hubball and Burt (2007) stated that students could demonstrate learning experiences through case-based courses and capstone projects where e-portfolio assessment can provide an effective way to present and record project experiences. 


\section{Previous Studies}

One of the best sources for assessing teaching excellence and students' learning outcomes is the students themselves as students complete and provide evaluations and summative feedback about the course. Its outcomes will enable teachers and programme designers to open doors to improvement (Paolini, 2015). Action research by Hubball and Burt (2007) provided a holistic framework for evaluating learning outcomes for an undergraduate programme. One of the findings highlights the need for students to be self-assessed on their achievements through various learning and assessment methods. Kumpas-Lenk, Eisenschmidt, and Veispak (2018) advocated the importance of getting students' feedback on learning outcomes and student-centredness in designing learning outcomes through their findings that the achievement of learning outcomes is highly related to the students' perception of their engagement as these are based on the students' satisfaction and motivation. In a study investigating STEM students' perception of quality learning, Choy, Yim and Tan (2018) reported that learning outcomes have a high mediating relationship with learning skills and a partial mediating relationship with delivery and support, curriculum, and learning environment resources. Goh et al (2017) found that in an e-learning course, students' feedback revealed that their interaction with the instructor and their peers are significant factors contributing to students' satisfaction and achievement of learning outcomes. Pauline et al (2017) reported that one of the methods to assess the attainment of the performance index and programme learning outcomes required by an engineering program to be accredited was through students' exit survey, where they were required to appraise themselves each PLO.

These studies suggest that students' perspectives are important, as stated by Aziz, Yusof and Yatim (2012), where they found that such input from students will allow for assessing the actual quality in teaching and learning by providing good learning outcomes. A study by Hashim and Abd Latif (2019) evaluated a master's project course outcomes through survey feedback found both agreements and contradictions between marks awarded by the supervisors and the student's perception of the learning outcomes achievement. Even though the students showed understanding that they have managed to achieve the CLOs, they acknowledged the challenges in writing the project report, which the supervisors did not indicate in their marking/grading (Hashim \& Abd Latif, 2019).

\section{Methods}

\section{Samples \& Research Procedures}

The sample for this study were 63 final semester students of LG120 Diploma in English for Professional Communication from Universiti Teknologi MARA Cawangan Melaka and Universiti Teknologi MARA Cawangan Johor. These students were chosen as they have completed the project-based course as required by the programme structure. Students were asked to answer an online survey form during the final week of the semester as this is deemed a suitable time for self-assessment and collecting feedback.

\section{Instrument}

Developed using Google Form, the online survey utilised 5-point rating scales ranging from 1 (strongly disagree) to 5 (strongly agree) for all items. The survey consisted of three sections. The first section recorded the demographic information of the respondents. Section Two elicited the Project and Portfolio assessment responses, while Section Three produced 
responses for the Poster Presentation assessment. The items listed were adapted from explanatory statements and descriptors from MQF's Domains of Learning Outcomes Cluster 3, Functional Work Skills-focus on Practical Skills, and Cluster 4, Personal and Entrepreneurial Skills as stated in the MQAs Malaysian Qualifications Framework 2.0 (2017) and Programme Standards: Language (2019). Sections Two and Three were assigned 17 items each, whereby six items are from Cluster 3 (Functional Work Skills-Practical Skills) and 11 items from Cluster 4 (Personal and Entrepreneurial Skills). Table 1 shows the sections of the questionnaire and items extracted from the questionnaire. A complete list of the items is available in Appendix 1.

Table 1

\begin{tabular}{ll}
\hline Section & Items \\
\hline Section 1: Demographic Information &
\end{tabular}

Section 2: Project and Portfolio Assessment

Section 3: Poster Presentation Assessment

\section{Cluster 3 (6 items): Functional Work Skills - Practical Skills}

- Apply various English language and professional communication skills to respond to and present ideas

- Apply the skills of planning and organisational skills

- Make adjustments to the practices and processes

\section{Cluster 4 (11 items): Personal and Entrepreneurial Skills}

- Identify self-improvement initiatives for further education/learning

- Develop realistic career and professional goals

- Explore activities relating to entrepreneurship

- Participate in professional activities leading to local and region-wide communities building

\section{Data Analysis \\ Reliability Test}

Upon conducting fundamental data analysis, reliability of the data was performed using Cronbach's Alpha. Table 2 shows that the Cronbach's Alpha values for Section Two: Functional Work Skills-Practical Skills was .967, Section Two: Personal and Entrepreneurial Skills was .944, Section Three: Functional Work Skills-Practical Skills was .947 and Section Three: Personal and Entrepreneurial Skills was .962.

Table 2

Section Cronbach Alpha Value $\quad$ N of Items




\begin{tabular}{lll}
\hline $\begin{array}{l}\text { Section 2 } \\
\text { Functional Work Skills-Practical }\end{array}$ & .967 & 6 \\
Skills & .944 & 11 \\
$\begin{array}{l}\text { Personal and Entrepreneurial } \\
\text { Skills }\end{array}$ & \\
\hline $\begin{array}{l}\text { Section 3 } \\
\text { Functional Work Skills-Practical }\end{array}$ & .947 & 6 \\
$\begin{array}{l}\text { Skills } \\
\text { Personal and Entrepreneurial }\end{array}$ & .962 & 11 \\
Skills & & \\
\hline
\end{tabular}

\section{Results}

The results of the study are presented based on the research questions through mean values and standard deviation. Descriptive statistical analysis of means and standard deviations was applied for this study to measure and interpret the responses.

Students' Perception on Attributes/Sub-attributes of Practical Skills and Personal and Entrepreneurial Skills Employed in the Project and Portfolio Assessments

Mean values and standard deviation of students' perception on the achievement of the attributes/sub-attributes engaged during the project and portfolio assessment are shown in Table 3. The highest mean score of 4.43 was recorded by 'make adjustments to the practices and processes carried out during the project (and portfolio)'. High scoring means of 4.41 and 4.40 were also recorded for 'apply the skills of planning and organisational skills throughout the process of the project and the portfolio', 'apply a range of skills in selecting methods and procedures suitable for the completion of the project and portfolio', and 'reflect on practices and processes undertaken during the project (and portfolio)' respectively. The lowest mean score recorded was 4.27 for 'apply various English language and professional communication skills to respond to and present ideas during the project (and portfolio)'.

Table 3.

Functional Work Skills-Practical Skills Outcomes Employed During Project And Portfolio 


\begin{tabular}{lll}
\hline Practical Skills Descriptors & Mean & SD \\
\hline $\begin{array}{l}\text {-apply various English language and professional } \\
\text { communication skills to respond to and present ideas during }\end{array}$ & .63 \\
the project (and portfolio). & \\
\hline $\begin{array}{l}\text {-apply the skills of planning and organisational skills } 4.41 \\
\text { throughout the process of the project and the portfolio. }\end{array}$ & .66 \\
\hline $\begin{array}{l}\text {-apply a range of skills in selecting tools, materials and } 4.29 \\
\text { technology as required by the project and portfolio. }\end{array}$ & .66 \\
\hline $\begin{array}{l}\text {-apply a range of skills in selecting methods and procedures } \\
\text { suitable for the completion of the project and portfolio. }\end{array}$ & .66 \\
\hline $\begin{array}{l}\text {-reflect on practices and processes undertaken during the } \\
\text { project (and portfolio). }\end{array}$ & \\
\hline $\begin{array}{l}\text {-make adjustments to the practices and processes carried out } \\
\text { during the project (and portfolio). }\end{array}$ & .66 \\
\hline
\end{tabular}

For the project and portfolio's achievements of personal and entrepreneurial skills descriptors, most of the items recorded a mean of above 4 with the highest being 4.40 ('identify self-improvement possibilities for further education/learning') followed by 4.38 ('identify self-improvement initiatives for further education/learning'). The results also showed that students considered that they had the opportunity to 'develop realistic career professional goals' (4.29) and 'identify common problems and/or issues in English and professional communication occurring in the social and professional community' (4.25). The lowest mean recorded was for the descriptor 'participate at civic activities leading to local and region-wide communities building' (3.84)

Table 4

Personal And Entrepreneurial Skills Employed During Project And Portfolio 


\begin{tabular}{|c|c|c|}
\hline Personal and Entrepreneurial Skills Descriptors & Mean & SD \\
\hline $\begin{array}{l}\text {-identify self-improvement initiatives for further } \\
\text { education/learning. }\end{array}$ & 4.38 & .73 \\
\hline $\begin{array}{l}\text {-identify self-improvement possibilities for further } \\
\text { education/learning. }\end{array}$ & 4.40 & .69 \\
\hline -develop realistic career professional goals. & 4.29 & .75 \\
\hline -explore activities relating to entrepreneurship. & 4.11 & .83 \\
\hline -engage in activities relating to entrepreneurship. & 4.13 & .87 \\
\hline $\begin{array}{l}\text {-show interest in professional activities leading to local and } \\
\text { region-wide communities building. }\end{array}$ & 4.08 & .77 \\
\hline $\begin{array}{l}\text {-show interest in civic activities leading to local and region- } \\
\text { wide communities building. }\end{array}$ & 4.08 & .79 \\
\hline $\begin{array}{l}\text {-participate in professional activities leading to local and } \\
\text { region-wide communities building. }\end{array}$ & 4.05 & .83 \\
\hline $\begin{array}{l}\text {-participate in civic activities leading to local and region-wide } \\
\text { communities building. }\end{array}$ & 3.84 & .97 \\
\hline $\begin{array}{l}\text {-identify common problems and/or issues in English and } \\
\text { professional communication occurring in the social and } \\
\text { professional community. }\end{array}$ & 4.25 & .70 \\
\hline $\begin{array}{l}\text {-resolve (identified) problems and/or issues in English and } \\
\text { professional communication occurring in the social and } \\
\text { professional community. }\end{array}$ & 4.17 & .80 \\
\hline
\end{tabular}

Students' Perception on Attributes/Sub-attributes of Practical Skills and Personal and Entrepreneurial Skills Employed during the Poster Presentation Assessment

For the poster presentation assessment, the practical skill with the highest mean score was 'apply the skills of planning and organisational skills throughout the process of the presentation' (4.38). Three descriptors recorded the identical mean scores of 4.30; 'apply a range of skills in selecting tools, materials, and technology as required by the presentation', 'apply a range of skills in selecting methods and procedures suitable for the presentation', and 'reflect on practices and processes undertaken during the presentation'. The descriptors with the lowest means recorded were 'apply various English language and professional communication skills to respond to and present ideas during presentation' (4.21) and 'make adjustments to the practices and processes carried out during the presentation' (4.22).

Table 5

Functional Work Skills-Practical Skills Outcomes Employed During Poster Presentation 


\begin{tabular}{|c|c|c|}
\hline Practical Skills Descriptors & Mean & SD \\
\hline $\begin{array}{l}\text {-apply various English language and professional } \\
\text { communication skills to respond to and present ideas during } \\
\text { the presentation. }\end{array}$ & 4.21 & .63 \\
\hline $\begin{array}{l}\text {-apply the skills of planning and organisational skills } \\
\text { throughout the process of the presentation. }\end{array}$ & 4.38 & .63 \\
\hline $\begin{array}{l}\text {-apply a range of skills in selecting tools, materials and } \\
\text { technology as required by the presentation. }\end{array}$ & 4.30 & .69 \\
\hline $\begin{array}{l}\text {-apply a range of skills in selecting methods and procedures } \\
\text { suitable for the presentation. }\end{array}$ & 4.30 & .73 \\
\hline $\begin{array}{l}\text {-reflect on practices and processes undertaken during the } \\
\text { presentation. }\end{array}$ & 4.30 & .64 \\
\hline $\begin{array}{l}\text {-make adjustments to the practices and processes carried } \\
\text { out during the presentation. }\end{array}$ & 4.22 & .75 \\
\hline
\end{tabular}

Attainment of the personal and entrepreneurial skills descriptors for the poster presentation assessment is presented in Table 6 . The highest means recorded were 'identify selfimprovement initiatives for further education/learning' (4.38) and 'identify self-improvement possibilities for further education/learning' (4.33). Almost all of the other descriptors recorded an average of above 4.0, such as 'develop realistic career professional goals' (4.25), 'resolve (identified) problems and/or issues in English and professional communication occurring in the social and professional community' (4.22), and 'identify common problems and/or issues in English and professional communication occurring in the social and professional community' (4.19). The lowest mean recorded was 'participate at civic activities leading to local and region-wide communities building (social and professional connections)' (3.87).

Table 6

Personal And Entrepreneurial Skills Employed During Poster Presentation 


\begin{tabular}{|c|c|c|}
\hline Personal and Entrepreneurial Skills Descriptors & Mean & SD \\
\hline $\begin{array}{l}\text {-identify self-improvement initiatives for further } \\
\text { education/learning. }\end{array}$ & 4.38 & .73 \\
\hline $\begin{array}{l}\text {-identify self-improvement possibilities for further } \\
\text { education/learning. }\end{array}$ & 4.33 & .70 \\
\hline -develop realistic career professional goals. & 4.25 & .76 \\
\hline -explore activities relating to entrepreneurship. & 4.08 & .79 \\
\hline -engage in activities relating to entrepreneurship. & 4.10 & .80 \\
\hline $\begin{array}{l}\text {-show interest in professional activities leading to local and } \\
\text { region-wide communities building. }\end{array}$ & 4.10 & .82 \\
\hline $\begin{array}{l}\text {-show interest in civic activities leading to local and region- } \\
\text { wide communities building. }\end{array}$ & 4.06 & .82 \\
\hline $\begin{array}{l}\text {-participate in professional activities leading to local and } \\
\text { region-wide communities building. }\end{array}$ & 4.02 & .87 \\
\hline $\begin{array}{l}\text {-participate in civic activities leading to local and region-wide } \\
\text { communities building. }\end{array}$ & 3.87 & .83 \\
\hline $\begin{array}{l}\text {-identify common problems and/or issues in English and } \\
\text { professional communication occurring in the social and } \\
\text { professional community. }\end{array}$ & 4.19 & .76 \\
\hline $\begin{array}{l}\text {-resolve (identified) problems and/or issues in English and } \\
\text { professional communication occurring in the social and } \\
\text { professional community. }\end{array}$ & 4.22 & .79 \\
\hline
\end{tabular}

\section{Discussion}

The findings of this study indicated that the students believed that the learning activities aligned to the project and portfolio, and poster presentation assessment methods managed to achieve the intended learning outcomes. Almost all descriptor statements that were stated in the survey recorded high mean scores. This is comparable to Hashim and Abd Latif's (2019) findings, where students indicated that they understood the CLO statements and might have a clear insight into what they are expected and required to perform and achieve by the end of the course.

In terms of the CLOs, the results indicated that the students believed they had achieved the intended learning outcomes. CLO1's 'performing essential methods and procedures' descriptor item of 'apply various English language and professional communication skills' scored mean values above 4.0 for both the project and portfolio and poster presentation assessments. The same results are also apparent for CLO2 'initiate entrepreneurial mindsets' and its corresponding descriptor 'explore activities relating to entrepreneurship'. Even though the CLOs' corresponding items did not score the highest mean values, but they were still respectably high, indicating that these learning outcomes were achieved by the course design and assessments.

Most importantly, the findings reveal that the course design has over-achieved the intended learning outcomes. CLO1 and CLO2 mention the attributes of 'performing essential methods and procedures' and 'initiate entrepreneurial mindsets' as the main outputs. Based on the project and portfolio assessment findings, it is evident that students could make adjustments to the practices and processes carried out during the project (and portfolio). This indicates that the assessment has helped the students improve their practical skills where they could perform essential methods and procedures while conducting the project. 
Additionally, students were able to initiate an entrepreneurial mindset through project and portfolio assessment. This can be seen when the findings show that students could identify the possibilities to improve themselves for further education/learning. As for poster presentation assessment, the findings show that the students were able to apply the skills of planning and organisational skills throughout the presentation. Planning and organisational skills, which involve processes such as planning, leading, organising, coordination and control are among the important skills set that graduates should have in order to remain relevant in today's workplace realities (Shariff, Johan, \& Jamil, 2013; Wan Mohamad \& Abd Majid, 2017). Besides that, the poster presentation assessment has helped the students identify the possibilities of improving themselves for further education/learning.

However, the findings suggest that students also performed the other attributes/subattributes as other descriptors that were not stated in the course CLOs also scored high mean values. This could be due to the holistic and comprehensive nature of the project-based work undertaken by the students that promote and allow for the generation of new ideas either individually or as a group to solve or to work with identified issues (Halim, Buniyamin, Imazawa, Naoe, \& Ito, 2014). Furthermore, students who engaged in the industry via their project were able to gain valuable learning experiences and visions about future career and employment opportunities (Burns \& Chopra, 2017).

\section{Conclusion}

Based on the findings, it can be concluded that the students who completed this final undergraduate semester project-based course are convinced that they have achieved the learning outcomes of this course. Furthermore, the results suggested that other attributes/sub-attributes of the MQF's Domains of Learning Outcomes Cluster 3, Functional Work Skills-focus on Practical Skills, and the students also employed Cluster 4, Personal and Entrepreneurial Skills during the course.

The present study highlights the importance of understanding students' perception of their attainment of intended learning outcomes at the end of this course and strengthens the position that students' views must be considered when writing or creating a programme, course and learning outcomes. The findings of this study will enable the course developers to make decisions related to the learning outcomes that are or could be achieved by this final semester project course. The programme committee and other higher learning providers can also use the findings during curriculum review to determine suitable course design and assessments. Further research can be conducted to include the perception of lecturers, supervisors, and industry. Another area that could be investigated is the type of projects undertaken by the students and the level of engagement with stakeholders that contribute to the achievement of the learning outcomes. This study has shown that students' perception is invaluable when evaluating and determining learning outcomes.

\section{Acknowledgement}

The authors would like to thank all those who contributed to the completion of this research.

\section{Declaration}

The authors would like to declare no conflict of interests.

\section{References}


Aithal, P. S., \& Kumar, P. M. (2016). Student performance and learning outcomes in higher education institutions. International Journal of Scientific Research and Modern Education (IJSRME), 1(1), 674-684.

Aziz, A. A., Yusof, K. M., \& Yatim, J. M. (2012). Evaluation on the effectiveness of learning outcomes from students' perspectives. Procedia - Social and Behavioral Sciences, 56, 22-30. doi:10.1016/j.sbspro.2012.09.628

Burns, C., \& Chopra, S. (2017). A meta-analysis of the effect of industry engagement on students learning in undergraduate programs. The Journal of Technology, Management, and Applied Engineering, 33(1), 2-20.

Choy, S. C., Yim, J. S., \& Tan, P. L. (2018). The mediating effects of quality learning on the overall learning experience and learning outcomes of STEM Malaysian students. ICHSS 2018 (p. 05004). SHS Web of Conferences. doi:https://doi.org/10.1051/shsconf/20185305004

Elsheikh, E. M., Sarudin, I., \& Gunawan, T. S. (2017). A systematic approach for developing course learning outcomes to fulfil accreditation requirements in Malaysia. 2017 7th World Engineering Education Forum (WEEF) (pp. 428-433). IEEE.

Goh, C. F., Leong, C. M., Kasmin, K., Hii, P. K., \& Tan, O. K. (2017). Students' experiences, learning outcomes and satisfaction in e-learning. Journal of e-Learning and Knowledge Society, 13(2), 117-128. doi:10.20368/1971-8829/1298

Gosling, D., \& Moon, J. (2001). How to use learning outcomes and assessment criteria. London: SEEC.

Halim, M. A., Buniyamin, N., Imazawa, A., Naoe, N., \& Ito, M. (2014, December). The role of final year project and capstone project in undergraduate engineering education in Malaysia and Japan. In 2014 IEEE 6th Conference on Engineering Education (ICEED) (pp. 1-6). IEEE.

Hashim, H., \& Abd Latif, S. S. (2019). Evaluation of master's project course learning outcomes at Open University of Malaysia. ASEAN Journal of Open \& Distance Learning, 11(1), 4351.

Hubball, H., \& Burt, H. (2007). Learning outcomes and program-level evaluation in a four-year undergraduate pharmacy curriculum. American Journal of Pharmaceutical Education, 71(5), 1-8.

Jailani, A. I., Yusuf, M. A. H., Hoo, F. J., Ayob, N. M., Maulan, S., \& Jani, M. R. (2015). An analysis of a new proposed programme: A glimpse into MEB 2015-2025 for Higher Education. Sixth International Language Learning Conference 2015 (pp. 297-307). Penang, Malaysia: Universiti Sains Malaysia.

Keshavarz, M. (2011). Measuring course learning outcomes. Journal of Learning Design, 4(4), 1-9.

Kumpas-Lenk, K., Eisenschmidt, E., \& Veispak, A. (2018). Does the design of learning outcomes matter from students' perspective? Studies in Educational Evaluation, 59, 179-186. doi:https://doi.org/10.1016/j.stueduc.2018.07.008

Mahajan, M., \& Singh, S. M. K. (2017). Importance and benefits of learning outcomes. IOSR Journal of Humanities and Social Science, 22(3), 65-67. doi:10.9790/0837-2203056567

Malaysian Qualification Agency. (2019). Programme standards: Language. Cyberjaya, Selangor: Malaysian Qualifications Agency.

Malaysian Qualifications Agency. (2017). Malaysian qualifications framework (MQF) 2nd Edition. Petaling Jaya, Malaysia: Malaysian Qualifications Agency. 
Mohayidin, M., Suandi, T., Mustapha, G., Konting, M., Kamaruddin, N., Man, N., . . A Abdullah, S. (2008). Implementation of outcome-based education in Universiti Putra Malaysia: A focus on students' learning outcomes. International Education Studies, 1(4), 147160.

Paolini, A. (2015). Enhancing teaching effectiveness and student learning outcomes. Journal of Effective Teaching, 15(1), 20-33.

Pauline, O., Taib, H., Azlan, M. A., Nasir, N. F., Azmi, M. A., Salleh, S. M., . . Rahman, H. A. (2017). Assessment and evaluation for programme learning outcomes in Faculty of Mechanical and Manufacturing Engineering, Universiti Tun Hussein Onn Malaysia. International Conferenceon Applied Science (ICAS2016). 165 , pp. 1-11 (012033). IOP Conf. Series: Materials Science and Engineering. doi:10.1088/1757899X/165/1/012033

Shariff, S. M., Johan, Z. J., \& Jamil, N. A. (2013). Assessment of project management skills and learning outcomes in students' projects. Procedia - Social and Behavioral Sciences, 90, 745-754. doi:doi: 10.1016/j.sbspro.2013.07.148

Mohamad, W. N., \& Abd Majid, F. (2017). Overview: Super skills for the 21st century. In F. Abd Majid, A. A. Md Zamin, \& M. F. Kamarudin, Toolkits for 21st century teaching: Practical implications for the 4th industry skills development (pp. 1-9). Shah Alam, Selangor: UiTM Press.

Zain, N. M., Hadi, A. A., \& Hamid, K. A. (2016). Outcome based education: A perception from private health sciences graduating scholars in Malaysia. European Journal of Education Studies, 2(6), 78-86. doi:10.5281/zenodo.160233 
Appendix

Appendix-1

Survey Items

\section{SECTION TWO: STUDENTS' LEARNING OUTCOMES DOMAINS ACHIEVEMENT FOR PROJECT \& PORTFOLIO}

As a student of ELS304 Professional Communication Exercise, the individual project and portfolio had enabled/made me to...

Functional Work Skills: Practical Skills (Work skills and operational skills)

1 apply various English language and professional communication skills to respond to and present ideas during the project (and portfolio).

2 apply the skills of planning and organisational skills throughout the process of the project and the portfolio.

3 apply a range of skills in selecting tools, materials and technology as required by the project and portfolio.

4 apply a range of skills in selecting methods and procedures suitable for the completion of the project and portfolio.

$5 \quad$ reflect on practices and processes undertaken during the project (and portfolio).

6 make adjustments to the practices and processes carried out during the project (and portfolio).

\section{Personal and Entrepreneurial Skills}

7 identify self-improvement initiatives for further education/learning.

8 identify self-improvement possibilities for further education/learning (professional certificates / courses)

9 develop realistic career and professional goals

10 explore activities relating to entrepreneurship.

11 engage in activities relating to entrepreneurship.

12 show interest in professional activities leading to local and region wide communities building (social and professional connections).

13 show interest in civic activities leading to local and region wide communities building (social and professional connections).

14 participate at professional activities leading to local and region wide communities building (social and professional connections).

15 participate at civic activities leading to local and region wide communities building (social and professional connections).

16 identify common problems and/or issues in English and professional communication occurring in the social and professional community.

17 resolve (identified) problems and/or issues in English and professional communication occurring in the social and professional community.

\section{SECTION THREE: STUDENTS' LEARNING OUTCOMES DOMAINS ACHIEVEMENT FOR POSTER PRESENTATION}

As a student of ELS304 Professional Communication Exercise, the poster presentation had enabled/made me to...

Functional Work Skills: Practical Skills (Work skills and operational skills)

1 apply various English language and professional communication skills to respond to and present ideas during presentation. 


\begin{tabular}{|c|c|}
\hline 2 & $\begin{array}{l}\text { apply the skills of planning and organisational skills throughout the process of the } \\
\text { presentation. }\end{array}$ \\
\hline 3 & $\begin{array}{l}\text { apply a range of skills in selecting tools, materials and technology as required by the } \\
\text { presentation. }\end{array}$ \\
\hline 4 & apply a range skills in selecting methods and procedures suitable for the presentation. \\
\hline 5 & reflect on practices and processes undertaken during the presentation. \\
\hline \multirow[t]{2}{*}{6} & make adjustments to the practices and processes carried out during the presentation. \\
\hline & Personal and Entrepreneurial Skills \\
\hline 7 & identify self-improvement initiatives for further education/learning. \\
\hline 8 & identify self-improvement possibilities for further education/learning. \\
\hline 9 & develop realistic career and professional goals. \\
\hline 10 & explore activities relating to entrepreneurship. \\
\hline 11 & engage in activities relating to entrepreneurship. \\
\hline 12 & $\begin{array}{l}\text { show interest in professional activities leading to local and region wide communities } \\
\text { building (social and professional connections). }\end{array}$ \\
\hline 13 & $\begin{array}{l}\text { show interest in civic activities leading to local and region wide communities building } \\
\text { (social and professional connections). }\end{array}$ \\
\hline 14 & $\begin{array}{l}\text { participate at professional activities leading to local and region wide communities } \\
\text { building (social and professional connections). }\end{array}$ \\
\hline 15 & $\begin{array}{l}\text { participate at civic activities leading to local and region wide communities building } \\
\text { (social and professional connections). }\end{array}$ \\
\hline 16 & $\begin{array}{l}\text { identify common problems and/or issues in English and professional communication } \\
\text { occurring in the social and professional community. }\end{array}$ \\
\hline 17 & $\begin{array}{l}\text { resolve (identified) problems and/or issues in English and professional communication } \\
\text { occurring in the social and professional community. }\end{array}$ \\
\hline
\end{tabular}

